\title{
Analisis Pengaruh Konsumsi Kedelai, Produksi Kedelai Dan Cadangan Devisa Terhadap Impor Kedelai
}

\author{
Di Indonesia
}

\author{
Mahdoh $^{1}$, Havid Risyanto ${ }^{2}$ \\ Jurusan Ekonomi Syariah, Fakultas Ekonomi dan Bisnis Islam \\ Universitas Islam Negeri Sultan Maulana Hasanuddin Banten, Indonesia \\ Mahdoh96@gmail.com', havid.risyanto@uinbanten.ac.id ${ }^{2}$
}

\begin{abstract}
The agricultural sector is the primary sector and plays an important role for the national economy. One of the agricultural sectors is soybeans which is a staple food for the people of Indonesia. This study aims to determine the simultaneous and partial effects of consumption, production and foreign exchange reserves on soybean imports in Indonesia, as well as to analyze the variables that have the most dominant influence on soybean imports in Indonesia in the period 2000-2016. The method used in this study is a quantitative approach research and uses secondary data with time series and the analysis tool used is multiple linear regression analysis with the help of software Eviews 9. The results showed simultaneous consumption, production and reserve variables Foreign exchange has a significant impact on soybean imports in Indonesia for the period 2000-2016. Foreign exchange reserve variables have a positive and significant effect on soybean imports in Indonesia for the period 2000 2016.
\end{abstract}

Keywords : soybean consumption, soybean Production, foreign exchange reserves and soybean import

\begin{abstract}
Abstrak
Sektor pertanian merupakan sektor primer dan memegang peranan penting bagi perekonomian nasional. Salah satu dari sektor pertanian adalah kedelai yang merupakan termasuk makanan pokok bagi masyarakat Indonesia. Penelitian ini bertujuan untuk mengetahui pengaruh secara simultan dan parsial konsumsi, produksi dan cadangan devisa terhadap impor kedelai di Indonesia, serta untuk menganalisis variabel yang berpengaruh paling dominan terhadap impor kedelai di Indonesia pada periode tahun 2000-2016. Metode yang digunakan dalam penelitian ini adalah penelitian dengan pendekatan kuantitatif serta menggunakan data sekunder dengan runtun waktu (time series) dan alat analisis yang digunakan adalah analisis regresi linear berganda dengan bantuan perangkat lunak Eviews 9. Hasil penelitian menunjukan secara simultan variabel konsumsi, produksi dan cadangan devisa berpengaru signifikan terhadap impor kedelai di Indonesia periode tahun 2000-2016. Variabel cadangan devisa berpengaruh positif dan signifikan terhadap impor kedelai di Indonesia periode tahun 2000-2016.
\end{abstract}

Kata Kunci : Konsumsi Kedelai, Produksi Kedelai, Cadangan Devisa dan Impor Kedelai

\section{PENDAHULUAN}

Sektor pertanian merupakan sektor yang cukup sentral, dimana sektor ini berperan dalam pemenuhan kebutuhan pangan nasional, disamping sebagai indikator pembangunan negara berkembang. Hal ini sejalan dengan pernyataan Tulus T.H. Tambunan yang 
menyatakan bahwa Pembangunan ekomoni negara berkembang lebih unggul dalam pemanfaatan sumber daya alamnya. Pembangunan dibidang pertanian juga sangat penting karena sebagian besar masyarakat di negara-negara miskin atau sedang berkembang sangat menggantungkan hidupnya pada sektor pertanian. ${ }^{1}$

Pangan merupakan kebutuhan manusia yang paling mendasar yang harus dipenuhi sebagai wujud dari eksistensi manusia agar dapat bertahan hidup. Pemenuhan kebutuhan pangan yang cukup merupakan salah satu penentu bagi perwujudan ketahanan pangan nasional. ${ }^{2}$ Hal ini menjadi pekerjaan rumah bagi pemerintah untuk mewujudkan kemandirian dalam pengadaan komoditas-komoditas pertanian. ${ }^{3}$

Kedelai adalah salah satu tanaman polong-polongan dan merupakan sumber utama protein dan minyak nabati utama dunia. Kedelai merupakan tanaman pangan utama strategis terpenting setelah padi dan jagung. Begitu besarnya kontribusi kedelai dalam hal penyediaan bahan pangan bergizi bagi manusia sehingga kedelai biasa dijuluki sebagai Gold from the Soil, atau sebagai World's Miracle mengingat kualitas asam amino proteinnya yang tinggi, seimbang dan lengkap. Konsumsi kedelai oleh masyarakat Indonesia dipastikan akan terus meningkat setiap tahunnya mengingat beberapa pertimbangan seperti bertambahnya populasi penduduk, peningkatan pendapatan per kapita, kesadaran masyarakat akan gizi makanan. Rakyat mengolah kedelai menjadi berbagai produk pangan seperti tempe, tahu, tauco, kecap, susu dan lain-lain dengan permintaan yang selalu meningkat setiap tahunnya.

Peningkatan kebutuhan akan kedelai dapat dikaitkan dengan meningkatnya konsumsi masyarakat terhadap tahu dan tempe, serta untuk pasokan industri kecap. Dinamika perdagangan kedelai dunia dapat mempertajam posisi Indonesia dalam perdagangan internasional kedelai. Dengan mengetahui posisi kedelai Indonesia di pasar internasional, pemerintah dapat mengantisipasi kebijakan apa yang akan diambil untuk mendukung pembangunan ekonomi dan meningkatkan kesejahteraan petani. ${ }^{4}$

${ }^{1}$ Subandi, Ekonomi Pembangunan, (Bandung: Alfabeta, 2014).

${ }^{2}$ Rindi Anggoro Sukma, Analisis Faktor - Faktor Yang Mempengaruhi Impor Beras Di Indonesia Tahun 1980-2011, (Skripsi, Program Sarjana, Semarang: Universitas Negeri Semarang, 2012).

${ }^{3}$ T.H. Tulus Tambunan, Perekonomian Indonesia Era Orde Lama Hingga Jokowi, (Bogor: Ghalia Indonesia, 2015).

${ }^{4}$ Rizma Aldillah, Proyeksi Produksi dan Konsumsi Kedelai di Indonesia , (Jurnal Ekonomi Kuantitatif Terapan, Vol 8 (1), 2015). 
Meski jadi negara pengkonsumsi kedelai terbesar di dunia, ironinya kebutuhan kedelai Indonesia bergantung dari impor. Setiap tahun, rata-rata angka impor kedelai di atas 2 juta ton, sebagian besar berasal dari Amerika Serikat (AS). Direktur Perlindungan Tanaman Kementerian Pertanian (Kementan), Dwi Iswari, mengatakan untuk tahun 2016 sebanyak $68 \%$ kebutuhan kedelai ini dipasok dari impor. ${ }^{5}$ Produk impor merupakan barang-barang yang tidak dapat dihasilkan atau negara yang sudah dapat dihasilkan,tetapi tidak dapat mencukupi kebutuhan rakyat. ${ }^{6}$

Alasan suatu negara melakukan impor disebabkan adanya kegagalan negara tersebut dalam memenuhi kebutuhan dalam negeri, baik dalam bentuk kualitas maupun kuantitas. Ketidakmampuan suatu negara dalam menyediakan kebutuhan kedelai terjadi akibat negara tersebut tidak dapat berproduksi secara efisien, sehingga hasil panen kedelai dalam negeri selalu defisit untuk memenuhi kebutuhan konsumsi. ${ }^{7}$

\section{Gambar.1}

\section{Impor Kedelai di Indonesia}

Periode Tahun 2000-2016

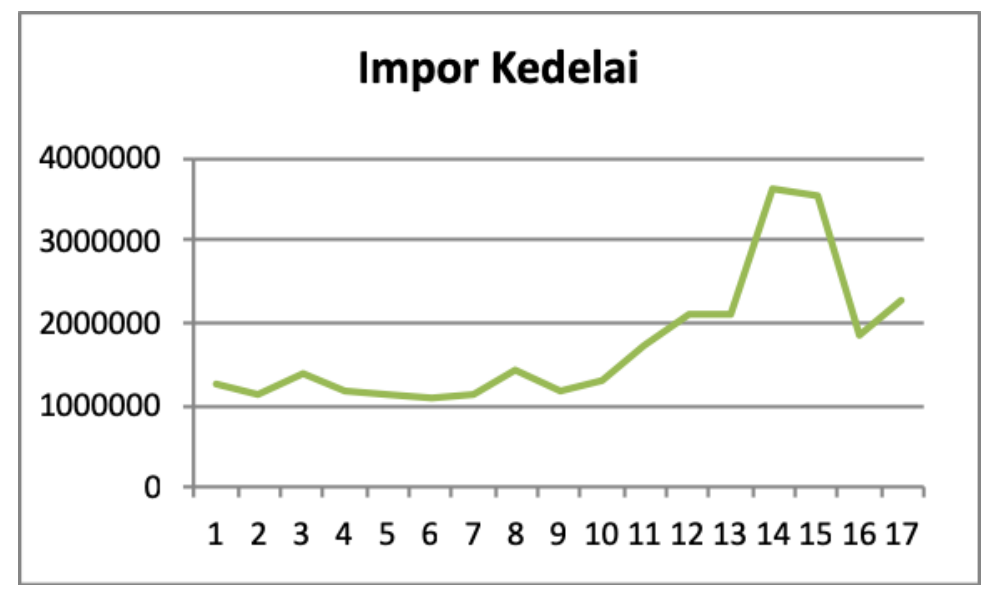

sumber : Badan Pusat Statistik (data diolah)

5 Muhammad Idris, Indonesia Negeri Tempe Tapi Impor Kedelai, (https://finance.detik.com/berita-ekonomi-bisnis/d-3372130/indonesia-negeri-tempe-tapi-imporkedelai, 2018).

${ }^{6}$ Putri Meliza Sari, dkk, Analisi faktor-faktor yang Mempengaruhi Produksi, Konsumsi dan Impor Kedelai di Indonesia, (Jurnal Kajian Ekonomi ,Vol III (5), 2014).

7 Iin Nurul Yulianti, Pengaruh Jumlah Uang Beredar (M2), Tingkat Suku Bunga SBI, Impor, dan Cadangan Devisa Terhadap Nilai Tukar Rupiah/Dolar Amerika Tahun 2001-2013, (Jurnal, Jurusan Ekonomi Pembangunan, Fakultas Ekonomi, Universitas Negeri Semarang, 2014). 
Jika dirinci berdasarkan negara asal, Indonesia mengimpor kedelai paling besar dari Amerika Serikat dengan 238,8 ribu ton setara US\$ 106,4 juta. Kedua, berasal dari Kanada dengan volume 2.076 ton yang nilainya US\$ 970,6 ribu. Ketiga, dari Malaysia sebanyak 738,7 ton dengan nilai US\$ 387,9 ribu. Keempat, berasal dari Benin sebesar 531,0 ton dengan nilai US\$ 199,6 ribu. Sedangkan khusus Singapura, Indonesia tidak melakukan impor kedelai terhitung sejak Januari-April 2017. Jika dilihat dari Januari-April 2017, total impor kedelai mencapai 1,04 juta ton dengan nilai US\$ 467,01 juta. Sedangkan Januari-April 2016 mencapai 767,3 ribu ton dengan nilai US\$ 305,3 juta. ${ }^{8}$

Pembiayaan dalam perdagangan internasional sangat tergantung pada cadangan devisa suatu negara. Karena cadangan devisa merupakan penentu penting bagi negara berkembang sebagai permintaan impor, ${ }^{9}$ karena dalam perdagangan internasional mewajibkan menggunaka valuta asing pada setiap pembayaran yang dilakukan. Menurut Hartoyo dan Noorma pendapatan sangat berpengaruh bagi kelangsungan hidup perusahaan, semakin besar pendapatan yang diperoleh maka semakin besar kemapuan perusahaan untuk membiayai segala pengeluaran dan kegiatan-kegiatan yang dilakukan oleh perusahaan, dalam hal ini adalah cadangan devisa yang dimiliki oleh Indonesia.

\section{LANDASAN TEORI}

Suatu negara akan melakukan impor karena produksi dalam negeri tidak mampu mencukupi kebutuhan sendiri atau bahkan negara sendiri tidak mampu memproduksi. Dengan terhambatnya kegiatan impor maka akan ikut terhambatnya kegiatan di dalam negeri. ${ }^{10}$ Teori perdagangan internasional menganalisis dasar-dasar terjadinya perdagangan internasional antar negara serta keuntungan yang diperoleh suatu negara dari pelaksanaan perdagangan internasional tersebut. Merkantilisme berkeyakinan bahwa perekonomian suatu negara makin makmur bila mampu memaksimalkan surplus perdagangan. Konsekuensinya

\footnotetext{
${ }^{8}$ Hendra Kusuma, Dalam Sebulan RI Impor Kedelai 242 Ton, Mayoritas dari AS, (https://finance.detik.com/berita-ekonomi-bisnis/d-3508804/dalam-sebulan-ri-impor-kedelai-242-ton-mayoritasdari-as, 2018).

${ }^{9} \mathrm{Z}$ Sultan, Foreigen Exchange Reserves and Indian's Impor Demand : A Cointegration and Vector Error Corection Analysist, (Collage of Bussiness Admistration, Al Kharaj University, International Jurnal of Bussiness and Management Vol. 6, 2009).

10 Reny Agustina, Pengaruh Ekspor, Impor, Nilai Tukar Rupiah, Dan Tingkat Inflasi Terhadap Cadangan Devisa Indonesia (Jurnal, Program Studi Akuntansi STIE Mikroskil, 2014)
} 
adalah memaksimalkan ekspor sekaligus meminimumkan impor. Dengan demikian surplus perdagangan akan maksimal. ${ }^{11}$

Berdasarkan rumusan masalah serta teori dan konsep yang telah dikemukakan, penelitian ini bertujuan untuk menganalisis pengaruh dari konsumsi kedelai, produksi dan cadangan devisa secara simultan atau bersama-sama terhadap impor kedelai di Indonesia juga untuk mengetahui dari ke tiga variabel independen atau bebas itu mana yang lebih memberikan pengaruh dominan terhadap impor kedelai di Indonesia perode ttahun 20002016.

\section{METODE PENELITIAN}

Metode penelitian yang digunakan dalam penelitian ini adalah penelitian kuantitatif sedangkan jenis data yang digunakan dalam penelitian ini merupakan data sekunder, yang bersumber pada laporan Badan Pusat Statistik (BPS) nasional dan PUSDATIN Kementrian Pertanian. Data yang diteliti meliputi Konsumsi Kedelai, Produksi Kedelai, Cadangan devisa dan Impor Kedelai di Indonesia. Jenis data yang digunakan adalah data time series yaitu runtun waktu pada tahun 2000-2016.

Pengolahan data menggunakan program Eviews 9, dengan model penelitian yang akan digunakan dalam penelitian ini adalah sebagai berikut: ${ }^{12}$

$$
Y_{t}=\beta_{0}+\beta_{1} X_{1 t}+\beta_{2} X_{2 t}+\beta_{3} X_{3 t}+\widetilde{\varepsilon t}
$$

Keterangan :

$\mathrm{Y}_{\mathrm{t}} \quad=$ Impor Kedelai (dalam ton)

$\mathrm{X}_{1 \mathrm{t}} \quad=$ Konsumsi Kedelai (dalam ton)

$\mathrm{X}_{2 \mathrm{t}} \quad=$ Produksi Kedelai (dalam ton)

$\mathrm{X}_{3 \mathrm{t}} \quad=$ Cadangan Devisa (dalam Rupiah)

$\mathrm{B}_{0} \quad=$ Intersep/Konstanta

$\beta_{1}, \beta_{2}, \beta_{3} \quad=$ Slope $/$ Koefisien Regresi

11 Prathama Rahardja, dan Manurung, Mandala, Teori Ekonomi Makro Sutau Pengantar Edisi Keempat, (Jakarta: Lembaga Penerbit Fakultas Ekonomi Universitas Indonesia, 2008).

12 Damodar Gujarati, dan Dawn C. Porter, Dasar-Dasar Ekonometrika, Ed. 5, (Jakarta: Salemba Empat, 2015). 
$\overline{\varepsilon t} \quad=$ Error/ Residual

Dalam analisis data, penelitian ini menggunakan analisis regresi linear berganda dengan tujuan untuk menduga dan atau meramalkan nilai rata-rata hitung atau rata-rata populasi dari variabel tak bebas (variabel dependen) berdasarkan pengetahuan mengenai nilai variabel bebas (variabel independen). beberapa pengujian untuk menganalisis data, diantaranya Uji Hipotesis yakni Uji Hipotesis secara Simultan (Uji F), Uji Hipotesis secara Parsial (Uji t) dan Koefisien Determinasi. Kemudian dilanjutkan dengan Uji Asumsi Klasik yang terdiri dari Uji Normalitas, Uji Multikolinearitas, Uji Heteroskedastisitas dan Uji Autokorelasi.

\section{HASIL DAN PEMBAHASAN}

Sebelum data dianalisis, dilakukan standarisasi atau normalisasi data. Normalisasi data mentah dilakukan agar data tersebut berada pada rentang yang sama. Berdasarkan dari hasil analisis dengan menggunakan program Eviews 9 maka diperoleh hasil regresi sebagai berikut :

\section{Tabel. 1}

Hasil Analisis Regresi Konsumsi, Produksi Kedelai dan Cadangan Devisa Terhadap Impor Kedelai di Indonesia Periode Tahun 2000-2016

\begin{tabular}{|c|c|c|c|c|}
\hline Variable & Coefficient & Std. Error & t-Statistic & Prob. \\
\hline $\mathrm{C}$ & $-5.50 \mathrm{E}-17$ & 0.162314 & $-3.39 \mathrm{E}-16$ & 1 \\
\hline ZKONSUMSI_KEDELAI & -0.285903 & 0.183159 & -1.560953 & 0.1425 \\
\hline ZPRODUKSI_KEDELAI & -0.094153 & 0.186129 & -0.505849 & 0.6214 \\
\hline ZCADANGAN_DEVISA & 0.895711 & 0.200115 & 4.475987 & 0.0006 \\
\hline R-squared & 0.636097 & \multicolumn{2}{|c|}{ Mean dependent var } & $6.53 \mathrm{E}-17$ \\
\hline Adjusted R-squared & 0.552119 & \multicolumn{2}{|c|}{ S.D. dependent var } & 1 \\
\hline S.E. of regression & 0.669239 & \multicolumn{2}{|c|}{ Akaike info criterion } & 2.236974 \\
\hline Sum squared resid & 5.822453 & \multicolumn{2}{|c|}{ Schwarz criterion } & 2.433024 \\
\hline Log likelihood & -15.01428 & \multicolumn{2}{|c|}{ Hannan-Quinn criter. } & 2.256461 \\
\hline F-statistic & 7.574592 & \multirow{2}{*}{\multicolumn{2}{|c|}{ Durbin-Watson stat }} & \multirow{2}{*}{1.505340} \\
\hline Prob(F-statistic) & 0.003521 & & & \\
\hline
\end{tabular}


Berdasarkan hasil Uji F diatas pada $\alpha=5 \%$ bahwa F hitung > F tabel yaitu 7.574592 $>$ 3, 13 atau $7.574592>3,41$ dan jika dilihat dengan nilai signifikansi bahwa nilai signifikansi $<0,05$ yaitu $0.003521<0,05$ maka $\mathrm{H}_{0}$ ditolak dan $\mathrm{H}_{\mathrm{a}}$ diterima. Maka dapat disimpulkan bahwa konsumsi kedelai, produksi kedelai dan cadangan devisa memiliki pengaruh signifikan terhadap impor kedelai di Indonesia periode tahun 2000-2016. Sedangkan uji hipotesis secara parsial diperoleh sebagai berikut:

1. Pengaruh Konsumsi Kedelai Terhadap Impor Kedelai di Indonesia Periode Tahun 2000-2016

Berdasarkan hasil regresi pada $\alpha=5 \%$ menunjukkan bahwa nilai t hitung $<\mathrm{t}$ tabel yaitu $-1.560953<2.16037$ dan jika dilihat dari nilai signifikansi bahwa nilai signifikansi > 0,05 yaitu sebesar 0.1425>0,05 maka, $\mathrm{H}_{0}$ diterima dan $\mathrm{H}_{1}$ ditolak. Maka dapat disimpulkan bahwa konsumsi kedelai tidak terbukti mempunyai pengaruh yang signifikan terhadap impor kedelai di Indonesia pada periode tahun 2000-2016.

2. Pengaruh Produksi Kedelai Terhadap Impor Kedelai di Indonesia Periode Tahun 2000-2016

Berdasarkan hasil regresi pada $\alpha=5 \%$ menunjukkan bahwa nilai t hitung $<\mathrm{t}$ tabel yaitu $-0.505849<2.16037$ dan jika dilihat dari nilai signifikansi bahwa nilai signifikansi > 0,05 yaitu sebesar 0.6214> 0,05 maka, $\mathrm{H}_{0}$ diterima dan $\mathrm{H}_{1}$ ditolak. Maka dapat disimpulkan bahwa produksi kedelai tidak terbukti mempunyai pengaruh yang signifikan terhadap impor kedelai di Indonesia pada periode tahun 2000-2016.

3. Pengaruh Cadangan Devisa Terhadap Impor Kedelai di Indonesia Periode Tahun 2000-2016

Berdasarkan hasil regresi pada $\alpha=5 \%$ menunjukkan bahwa nilai $\mathrm{t}$ hitung $>\mathrm{t}$ tabel yaitu $4.475987<2.16037$ dan jika dilihat dari nilai signifikansi bahwa nilai signifikansi $<0,05$ yaitu sebesar $0.0006<0,05$ maka, $\mathrm{H}_{0}$ ditolak dan $\mathrm{H}_{1}$ diterima. Maka dapat disimpulkan bahwa cadangan devisa terbukti mempunyai pengaruh yang signifikan dan positif terhadap impor kedelai di Indonesia pada periode tahun 20002016 
Setelah uji hipotesis dilakukan dan mendapatkan model yang tepat dalam menggambarkan data maka dilakukan uji asumsi klasik. Adapun uji asumsi klasik sebagai berikut :

\section{a. Uji Normalitas}

Uji Normalitas digunakan untuk melihat apakah data residual berdistribusi normal atau tidak dengan menguji hipotesis sebagai berikut :

$\mathrm{H}_{0}: \mathrm{p}$-value $<0,05$ maka data residual tidak berdistribusi normal

$\mathrm{H}_{\mathrm{a}}$ : p-value $>0,05$ maka data residual berdistriusi normal

\section{Gambar. 2}

\section{Hasil Output Uji Normalitas}
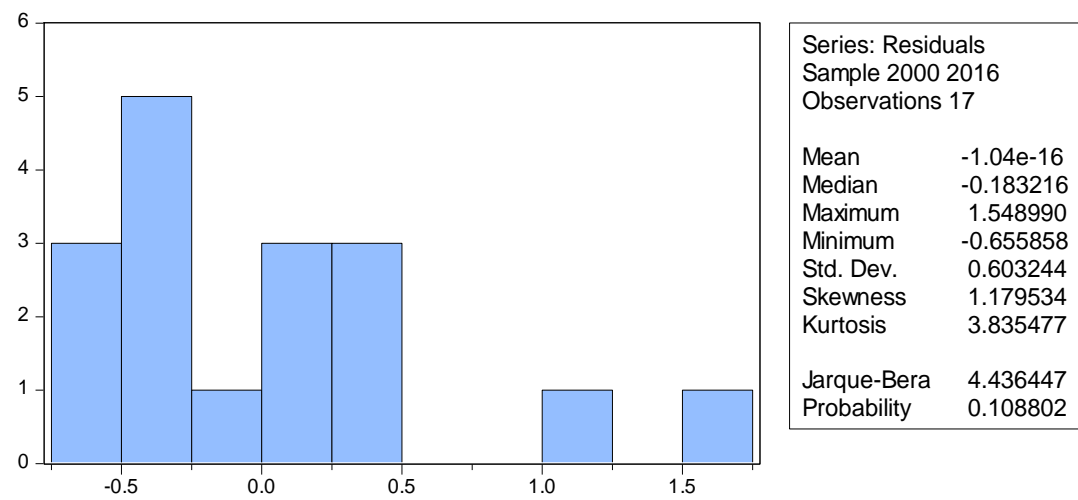

Dari tabel diatas, dapat dilihat bahwa nilai jarque bera sebesar 4,436447 dengan nilai probabilitas sebesar 0,108802, sehingga dapat dikatakan bahwa nilai probabilitas lebih besar dari taraf signifikansi sebesar 5\%. Hal ini dapat dikatakan bahwa data residual berdistribusi normal.

\section{b. Uji Multikolinearitas}

Uji multikolinearitas ini bertujuan untuk melihat apakah data pengamatan terdapat gejala multikolinearitas atau tidak. dengan menguji hipotesis sebagai berikut :

$\mathrm{H}_{0}: \mathrm{VIF}>10$ maka terdapat masalah multikolinearitas. 
I-Economic Vol. 4. No 2. Desember 2018 Analisis Pengaruh Konsumsi Kedelai .... Mahdoh, Hayid Risyanto

$\mathrm{H}_{\mathrm{a}}: \mathrm{VIF}<10$ maka tidak terdapat masalah multikolinearitas.

Tabel. 2

\section{Hasil Output Uji Multikolinearitas}

\begin{tabular}{|l|l|l|l|}
\hline \multirow{2}{*}{ Variable } & Coefficient & Uncentered & Centered \\
\cline { 2 - 4 } & Variance & VIF & VIF \\
\hline C & 0.026346 & 1.000000 & NA \\
\hline ZKONSUMSI_KEDELAI & 0.033547 & 1.198439 & 1.198439 \\
\hline ZPRODUKSI_KEDELAI & 0.034644 & 1.237619 & 1.237619 \\
\hline ZCADANGAN_DEVISA & 0.040046 & 1.430592 & 1.430592 \\
\hline
\end{tabular}

Berdasarkan nilai Multikolinearitas diatas, bahwa nilai VIF variable konsumsi kedelai menunjukkan nilai sebesar 1.198439 yang berarti kurang dari 10,00, variabel Produksi kedelai menunjukan nilai sebesar 1.237619 yang juga berarti kurang dari 10,00, dan variabel cadangan devisa menunjukan nilai sebesar 1.430592 yang juga kurang dari 10,00. Sehingga, dapat disimpulkan bahwa data tersebut tidak terjadi masalah multikolinearitas.

\section{c. Uji Heteroskedastisitas}

Uji Heteroskedastisitas dilakukan untuk mengetahui ada atau tidaknya penyimpangan asumsi klasik heteroskedastisitas yaitu adanya ketidaksamaan varian dari residual dengan menguji hipotesis sebagai berikut :

$\mathrm{H}_{0}$ : Probabilitas Obs* R-square $<0,05$ maka model regresi terdapat heteroskedastisitas.

$\mathrm{H}_{\mathrm{a}}$ : Probabilitas Obs* $\mathrm{R}$-square $>0,05$ maka model regresi tidak terdapat heteroskedastisitas.

Tabel. 3

\section{Hasil Output Uji White}

Heteroskedasticity Test: White 
I-Economic Vol. 4. No 2. Desember 2018 Analisis Pengaruh Konsumsi Kedelai .... Mahdoh, Hayid Risyanto

\begin{tabular}{|l|c|cc|l|}
\cline { 3 - 4 } F-statistic & 0.655033 & Prob. F(9,7) & 0.7285 \\
\hline Obs*R-squared & 7.771832 & $\begin{array}{c}\text { Prob. } \\
\text { Square(9) }\end{array}$ & Chi- & 0.5573 \\
\hline Scaled explained SS & 6.443301 & $\begin{array}{c}\text { Prob. } \\
\text { Square(9) }\end{array}$ & Chi- & 0.6949 \\
\hline
\end{tabular}

Berdasarkan hasil output diatas, diketahui bahwa nilai Prob. Chi square(9) pada Obs*R-Squared sebesar 0,5573 dengan nilai signifikansi sebesar 5\%. Maka dapat diketahui nilai $\mathrm{p}$ value 0,5573 lebih besar dari 0,05 berarti model regresi tersebut tidak ada masalah heteroskedastisitas.

\section{d. Uji Autokorelasi}

Uji Durbin Watson digunakan untuk menguji autokorelasi yang menilai adanya autokorelasi pada residual atau tidak dengan menguji hipotesis sebagai berikut :

$\mathrm{H}_{0}$ : maka tidak terdapat autokorelasi

$\mathrm{H}_{\mathrm{a}}$ : maka terdapat autokorelasi

Tabel. 4

\section{Hasil output Uji DW}

\begin{tabular}{|l|l|}
\hline Durbin-Watson stat & 1.505340 \\
\hline
\end{tabular}

Apabila dibandingkan dengan tabel DW, maka nilai DW statistic berada pada autokorelasi positif (+).

Tabel. 5

\section{Daerah Uji Durbin Watson}

\begin{tabular}{|l|l|l|l|l|} 
Korelasi & Tidak dapat & Tidak terjadi & Tidak dapat & Korelasi \\
$(+)$ & disimpulkan & Autokorelasi & disimpulkan & $(-)$ \\
\hline
\end{tabular}


I-Economic Vol. 4. No 2. Desember 2018 Analisis Pengaruh Konsumsi Kedelai .... Mahdoh, Hayid Risyanto

$\begin{array}{rrrrrrr}0 & \mathrm{dL} & \downarrow & \mathrm{du} & 2 & 4-\mathrm{du} & 4-\mathrm{dl} \\ 0 & 0.8572 & 1.505340 & 1,7101 & 2,2899 & 3,1428\end{array}$

Berdasarkan kesimpulan diatas, maka nilai DW terletak diantara nilai du dan $d_{L}$ yang berarti tidak memiliki keputusan yang pasti apakah terjadi autokorelasi atau tidak. Untuk mengatasi hal tersebut, maka dilakukan uji lanjutan menggunakan uji Breusch-Godfrey Serial Cerrelation LM Test dengan melihat kriteria uji sebagai berikut :

Jika Probabilitas Obs* R-square> 0,05 maka tidak terdapat Autokorelasi, atau

Jika Probabilitas Obs* R-square< 0,05 maka terdapat Autokorelasi

\section{Tabel. 6}

\section{Hasil Output Uji Breusch-Godfrey Serial Cerrelation LM Test}

\begin{tabular}{|l|l|l|l|}
\hline \multicolumn{4}{|l|}{ Breusch-Godfrey Serial Correlation LM Test: } \\
\hline F-statistic & 0.916767 & Prob. F(2,11) & 0.4283 \\
\hline Obs*R-squared & 2.428800 & Prob. Chi-Square(2) & 0.2969 \\
\hline
\end{tabular}

Berdasarkan hasil output diatas, diketahui bahwa nilai Prob Chi Square(2) sebesar 0,2969 dengan nilai signifikansi sebesar 0,05. Maka dapat diketahui bahwa nilai $\mathrm{p}$ value 0,2969 lebih besar dari 0,05. Sehingga dapat disimpulkan model regresi tersebut tidak ada masalah autokorelasi.

Berdasarkan hasil uji t diperoleh keterangan bahwa variabel konsumsi kedelai tidak berpengaruh signifikan terhadap impor kedelai di Indonesia pada periode tahun 2000-2016. Dengan Berdasarkan hasil regresi pada $\alpha=5 \%$ menunjukkan bahwa nilai t hitung $<\mathrm{t}$ tabel yaitu $-1.560953<2.16037$ dan jika dilihat dari nilai signifikansi bahwa nilai signifikansi > 0,05 yaitu sebesar $0.1425>0,05$. Hal tersebut karena, tingkat konsumsi kedelai yang dilakukan masyarakat bukan menjadi faktor utama pemerintah melakukan impor kedelai, karena memang seberapa besar konsumsi masyarakat baik terjadi peningkatan ataupun 
penurunan, pemerintah akan melakukan impor. Selain itu, intervensi pemerintah yang membatasi impor kedelai meskipun konsumsi dan perminataan kedelai semakin tinggi mengakibatkan tidak berpengaruhnya tingkat konsumsi kedelai terhadap impor kedelai di Indonesia.

Berdasarkan hasil uji t diperoleh keterangan bahwa variabel produksi kedelai tidak berpengaruh signifikan terhadap impor kedelai di Indonesia pada periode tahun 2000-2016. Berdasarkan hasil regresi pada $\alpha=5 \%$ menunjukkan bahwa nilai $\mathrm{t}$ hitung $<\mathrm{t}$ tabel yaitu $0.505849<2.16037$ dan jika dilihat dari nilai signifikansi bahwa nilai signifikansi $>0,05$ yaitu sebesar $0.6214>0,05$. Produksi kedelai dalam negeri tidak berpengaruh signifikan hal ini di sebabkan karena meskipun produksi dalam negeri meningkat, apabila cadangan kedelai yang ada tidak mencukupi kebutuhan cadangan kedelai minimum, maka pemerintah akan terus melakukan impor kedelai.

Berdasarkan hasil uji t diperoleh keterangan bahwa variabel cadangan devisa berpengaruh positif signifikan terhadap impor kedelai di Indonesia pada periode tahun 20002016. Berdasarkan hasil regresi pada $\alpha=5 \%$ menunjukkan bahwa nilai $\mathrm{t}$ hitung $>\mathrm{t}$ tabel yaitu $4.475987<2.16037$ dan jika dilihat dari nilai signifikansi bahwa nilai signifikansi < 0,05 yaitu sebesar $0.0006<0,05$. Menurut Kariyas (2008), cadangan devisa merupakan stok mata uang asing yang dimiliki negara dan sewaktu-waktu dapat digunakan untuk transaksi atau pembayaran internasional. Impor suatu negara biasanya dinyatakan aman apabila cadangan devisa mencukupi kebutuhan impor untuk jangka waktu setidak-tidaknya tiga bulan, cadangan devisa akan digunakan sebagai dasar pembiyaan untuk dilakukan impor kedelai.

\section{KESIMPULAN}

Berdasarkan hasil dari penelitian yang dilakukan terhadap pengaruh produksi kedelai, konsumsi kedelai dan cadangan devisa terhadap impor kedelai di Indonesia periode tahun 2000-2016 didapkan kesimpulan sebagai berikut :

1. Secara simultan variabel konsumsi kedelai, produksi kedelai dan cadangan devisa berpengaruh positif signifikan terhadap impor kedelai di Indonesia periode tahun 2000-2017, dengan memiliki koefisien determinasi atau $\mathrm{R}^{2}$ diperoleh nilai Adjusted $\mathrm{R}$-Squared $\left(\mathrm{R}^{2}\right)$ sebesar 0,552119. Hasil koefisien determinasi $\mathrm{R}^{2}$ menerangkan bahwa konsumsi kedelai, produksi kedelai dan cadangan devisa berpengaruh terhadap 
impor kedelai pada periode tahun 2000-2016 sebesar 55,21\% sedangkan sisanya $(100 \%-55,21 \%=44,79 \%)$ dipengaruhi atau dijelaskan oleh faktor-faktor lain yang tidak dimasukkan dalam model penelitian diataranya yaitu: pertumbuhan Ekonomi, Kurs, Harga Kedelai Nasional dan lain-lain.

2. Sedangkan untuk uji t atau uji secara parsial variabel cadangan devisa yang memiliki pengaruh yang dominan, Berdasarkan hasil regresi pada $\alpha=5 \%$ menunjukkan bahwa nilai t hitung > t tabel yaitu $4.475987<2.16037$ dan jika dilihat dari nilai signifikansi bahwa nilai signifikansi $<0,05$ yaitu sebesar $0.0006<0,05$ maka, $\mathrm{H}_{0}$ ditolak dan $\mathrm{H}_{\mathrm{a}}$ diterima. Maka dapat disimpulkan bahwa cadangan devisa terbukti mempunyai pengaruh yang signifikan dan positif terhadap impor kedelai di Indonesia pada periode tahun 2000-2016.

\section{DAFTAR PUSTAKA}

Agustina, Reny, 2014, Pengaruh Ekspor, Impor, Nilai Tukar Rupiah, Dan Tingkat Inflasi Terhadap Cadangan Devisa Indonesia, jurnal: Program Studi Akuntansi STIE Mikroskil.

Aldillah, Rizma. 2015. “Proyeksi Produksi dan Konsumsi Kedelai di Indonesia” , Jurnal Ekonomi

Kuantitatif Terapan, Vol 8 (1).

Benny, Jimmy. 2013. "Ekspor dan Impor Pengaruhnya Terhadap Posisi Cadangan Devisa di Indonesia”, Jurnal EMBA, Vol1(4).

Gujarati, Damodar N., dan Dawn C. Porter. 2015. Dasar-Dasar Ekonometrika, Ed. 5, Jakarta:

Salemba Empat.

Idris, Muhammad. 2018. "Indonesia Negeri Tempe Tapi Impor Kedelai", https://finance.detik.com/berita-ekonomi-bisnis/d-3372130/indonesia-negeri-tempetapi-impor-kedelai.

Kusuma, Hendra. 2018. "Dalam Sebulan RI Impor Kedelai 242 Ton, Mayoritas dari AS”, https://finance.detik.com/berita-ekonomi-bisnis/d-3508804/dalam-sebulan-ri-imporkedelai-242-ton-mayoritas-dari-as.

Rahardja, Prathama., dan Manurung, Mandala. 2008. Teori Ekonomi Makro Sutau Pengantar Edisi Keempat, Jakarta: Lembaga Penerbit Fakultas Ekonomi Universitas Indonesia.

Sari, Meliza, P., Aimon, Hasdi., dan Syofyan, Efrizal. 2014. “Analisi faktorfaktor yang Mempengaruhi Produksi, Konsumsi dan Impor Kedelai di Indonesia”, Jurnal Kajian Ekonomi, Vol III (5).

Sukma, Anggoro, R. 2012. “Analisis Faktor - Faktor Yang Mempengaruhi Impor Beras Di Indonesia

Tahun 1980-2011”, Skripsi, Program Sarjana, Semarang: Universitas Negeri Semarang. 
Subandi. 2014. Ekonomi Pembangunan, Bandung: Alfabeta.

Sugiartiningsih. 2012. "Pengaruh Luas Lahan Produksi, Terhadap Produksi Jagung di Indonesia

Periode 1990-2006”, Jurnal Ekono Insentif Kopwil4, Vol 6 (1).

Sugiyono. 2010. Statistik Untuk Pendidikan, Bandung: Alfabeta.

Supangat, Andi. 2007. STATISTIKA: Dalam Kajian Deskriptif, Inferensi, dan Nonparametik, Jakarta:

Kencana.

Sultan, Z. 2009. Foregen Exchange Reserves and Indian's Impor Demand : A Cointegration and

Vector Error Corection Analysist, Collage of Bussiness Admistration, Al Kharaj University,

International Jurnal of Bussiness and Management Vol. 6.

Tambunan, Tulus T.H. 2015. Perekonomian Indonesia Era Orde Lama Hingga Jokowi, Bogor:

Ghalia Indonesia.

Wahyudi, Tri, S. 2016. Konsep dan Penerapan Ekonometrika Menggunakan E-Views, Jakarta: PT.

Raja Grafindo Persada.

Yuliyanti, Nurul, I. 2014. "Pengaruh Jumlah Uang Beredar (M2), Tingkat Suku Bunga SBI, Impor,

dan Cadangan Devisa Terhadap Nilai Tukar Rupiah/ Dolar Amerika Tahun 20012013",

Jurnal, Jurusan Ekonomi Pembangunan, Fakultas Ekonomi, Universitas Negeri Semarang. 